\title{
腰椎外側神経根障害に対する内視鏡下手術の小経験
}

\author{
石 堂 康 弘*田邊史** 武富 栄 二** 山元 拓 哉* \\ 井 尻幸 成* 米和 徳* 小 宮 節 郎*
}

\section{Microendoscopic Spinal Surgery for Lateral Disc Herniation : A Report of Three Cases}

Yasuhiro Ishidou*, Fumito Tanabe**, Eiji Taketomi**, Takuya Yamamoto*, Kosei Ijiri*, Kazunori Yone*, and Setsuro Komiya*

腰椎外側神経維障害に対する観血的治療として，外側開空法や骨形成的椎弓切除による後方除圧，ある いは症例によっては椎間関節を切除して除圧し固定を併用するなどの方法がある. 我々は腰椎外側神経紺 障害に対し，内視鏡下に除圧術を行った 3 例を経験した．出血量は $50 \mathrm{~g}$ 前後で，合併症もなく，術後鎮 痛剂の使用も少ない傾向にありその成績も満足できるものであった．内視鏡手術は，明るく拡大された視 野であること, 斜視鏡であるため従来法で見えないところが見えるなどの利点から外側神経根障害に対し， 低侵襲で有用な術式であると考えられる. 注意点として術前のヘルニアの局在診断が重要であった。

Lateral approach, osteoplastic laminectomy or facetectomy, and spinal fusion were available for conventional surgical intervention of lumbar radiculopathy at the intra- or extraforaminal lesion. We performed microendoscopic disectomy on three cases of lateral disc herniation. All cases had little bleeding, less wound pain, no complications, and good results. Microendoscopic spinal surgery was less invasive and very useful for surgical treatment of lateral disc herniation. Preoperative imaging studies were important to identify the location of herniated disc.

Key words : microendoscopic spinal surgery（内視鏡下春椎手術）, microendoscopic disectomy（内 視鏡下椎間板切除術), lateral dsic herniation (外側ヘルニア), lessinvasive surgery (低侵襲手術)

\section{は じめに}

脊椎内視鏡下手術はその低侵襲性により術後創部痛 の軽減，早期退院，早期社会復帰などが可能となり， 患者にとっても医療経済的な観点からも利点があり本 邦でも急速に普及しつつある5). 今回, 我々は腰椎外 側神経根障害に対して 3 例の内視鏡下春椎後方手術を 経験し良好な成績であったので報告する.

\section{症例}

【症例 1】42 歳 男性 製造業

主訴は左下肢と腰痛．MRI 上，L1/2 にヘルニアを
認め，椎間板造影にて春柱管左側から上方へ migration しているのが認められる (図 1)。神経学的には 左で大腿神経進展テスト陽性，MMT で左大腿四頭筋 4 と筋力低下を認め, PTR が左で低下していた． L2 選択神経根ブロックで 5 割程度, L1 選択的神経根ブ ロックで 7 割程痛みが消失し， L $1 / 2$ の脊柱管内から 椎間孔内のヘルニアによる 2 根障害と診断し内視鏡下 椎間板摘出術 (Microendoscopic Disectomy : 以下 MED）を施行した．手術は，L1/2 の外側アプローチ にて L1 の外縁を部分椎弓切除しヘルニアを直視, 経 椎弓的にヘルニアを摘出した. 術後 8 日で退院, 術後 6 ケ月の最終調查時 JOA スコアは 11 点から 22 点に

\footnotetext{
* 鹿児島脊椎脊髄研究班鹿児島大学大学院運動機能修復学講座整形外科学 Department of Orthopaedic Surgery, Graduate School of Medical and Dental Sciences, Kagoshima University, Kagoshima, Japan

** 鹿児島脊椎脊䯣研究班鹿児島赤十字病院整形外科 Department of Orthopaedic Surgery, Kagoshima Red Cross Hospital, Kagoshima, Japan
} 


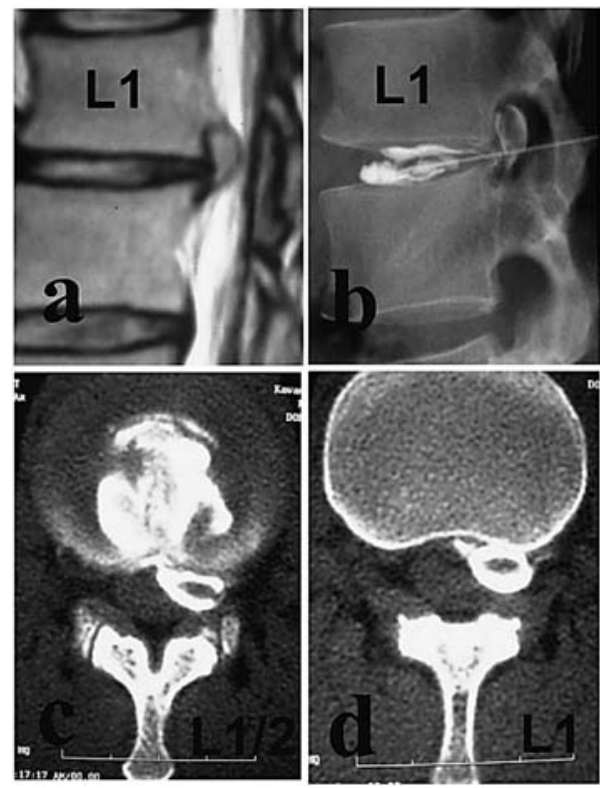

図 1 症例 1 MRI（a), 椎間板造影 (b), 椎間板 造影後 CT（c，d）にて L1/2 より脱出したへ ルニアが上方へ迷入し L1 椎間孔まで及んでい るのが確認された.

改善したが，術後リハビリ経過中に L4/5 のヘルニア による L5 神経根症出現しており復職はできていない.

【症例 2】34 歳 男性 運送業

主訴は左下肢痛と脱力．MRIでは明らかなへルニ アは描出されておらず，脊髄造影後 CT でも脊柱管内 の圧迫性病変は認めないが, 椎間板造影にて L $4 / 5$ の 左外側にヘルニアを認める（図 2)。神経学的には左 で大腿神経進展テスト陽性，MMT で左大腿四頭筋 4 と筋力低下を認めた． 左 L4 選択的神経根ブロックに て症状消失，L4/5 の外側にヘルニアによる L4 神経 根症と診断した。手術は，L4/5 の外側アプローチに て MED を施行しへルニアを摘出, 術後 9 日で退院, JOA スコアは 16 点から 27 点に改善, 仕事にも復職, 問題なく生活している.

【症例 3】78歳 女性 無職

平成 18 年 5 月中旬転倒し腰痛出現，その後腰痛増 強し左下肢痛も出現．近医にて骨粗鬆症による第 3 腰 椎の脆弱性椎体骨折の診断で保存的に加療するも左下 肢痛が耐えがたく入院. 単純 X-P, MRI にて第 3 腰 椎の椎体骨折を認めたが春柱管狭窄は認めず， L3/4 左外側に椎間板の膨隆を認めた（図 3)。春䯣造影で

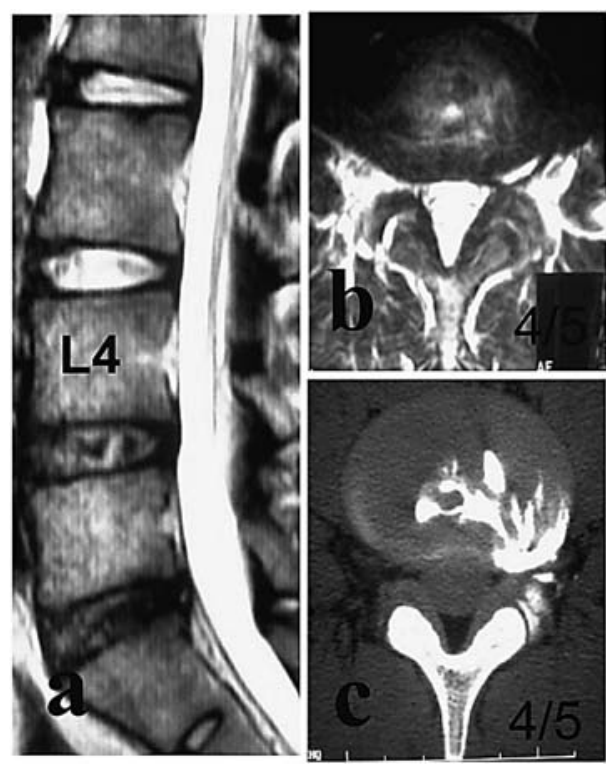

図 2 症例 2 MRI T2 強調画像矢状面 (a), 横断面 （b）では明らかな春柱管内での圧迫性病変は 認められないが，椎間板造影後 CT（c）にて L4/5 左外側にヘルニアを認めた。
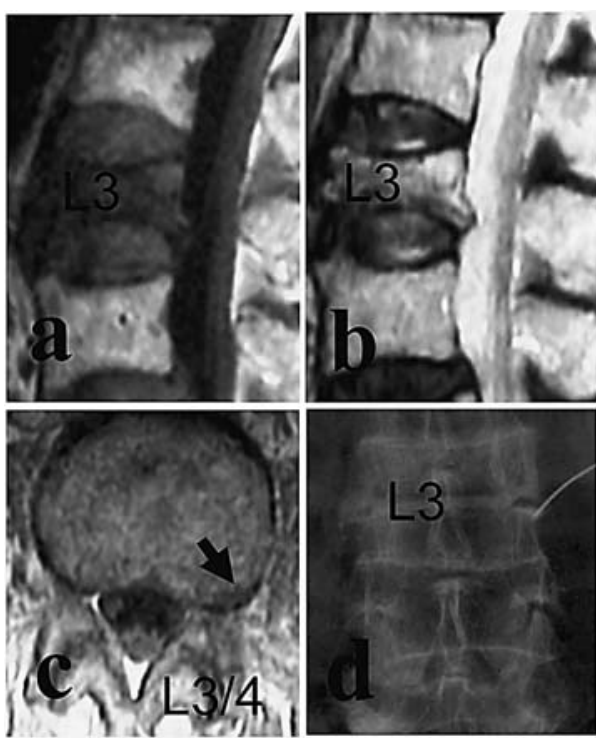

図 3 症例 3 MRI 矢状面 $\mathrm{T} 1$ 強調画像 (a), T2 強調画像（b）で第 3 腰椎の椎体骨折を認める. また T2 強調横断面 (c) にて左外側に突出し たヘルニアを認める. 左 L3 選択的神経根ブロッ ク（d）で症状の約 8 割が一時的に消失した. 
は L4 神経根囊像の欠損を認めたが，CT では明らか な脊柱管内の骨片の突出は認めなかつた。左 L4 選択 的神経根ブロックで 5 割程度, L3 選択的神経根ブロッ クで 8 割程度痛みが消失することから, 外側ヘルニア と L4 神経根の椎間孔入り口での狭窄による 2 根障害 と診断し MED を施行した. 手術は, 同一皮切より春 柱管内外からアプローチし ${ }^{3)}$ 脊柱管内左片側の除圧と 外側ヘルニアの摘出を行った. 術後, 35 日で退院し JOA は7点から 21 と改善, 術後 8 ケ月で隣接椎の新 たな骨折が発生しているが, 軽度の腰痛のみでコルセッ 卜着用下に下肢痛なく生活している.

\section{考察}

外側神経根障害によるコンベンショナルなアプロー チとして外側開空法, 骨形成的椎弓切除や, 椎間関節 切除を行い固定を追加するケースがある ${ }^{14)}$. 近年, 腰 椎椎間板ヘルニアに対する低侵襲手術として MED が 普及しつつあるが, 中でも明るく拡大された視野であ ること，斜視鏡であるため従来法で見えないところが 見えるなどの利点から MED が外側神経根障害に対し, 優れた術式であると報告されている ${ }^{6)}$ ，ただ，注意点 として術前のヘルニアの局在診断が重要である2).

今回の我々の症例でも, 出血量は $50 \mathrm{~g}$ 前後で, 合
併症もなく，術後鎮痛剂の使用も少ない傾向にありそ の成績も満足できるものであった，適応を選択するに あたつては, 必要に応じて MRI に加え春䯣造影や椎 間板造影，その後の CT まで行い，ヘルニアの局在を 正確に把握した上でヘルニアを摘出するルートについ て検討することが大切である.

結語

腰椎外側神経根障害に対して，内視鏡下脊椎後方手 術は優れた術式の 1 つであった.

\section{参 考 文 献}

1）岩村祐一ら：椎間孔内・外腰椎椎間板ヘルニアに対す る術式の検討。整形外科, $45: 1358-1364,1994$.

2) 三橋 雅ら：外側型腰椎椎間板ヘルニア摘出術におけ る MED の有用性. 関節鏡， $26 ： 173-177,2001$.

3）種市 洋ら：2 根障害をきたす特殊な腰椎椎間板へル ニア一単一椎間板に生じた春柱管内および椎間孔外へ ルニア合併例一. 臨整外, $29: 949-954,1994$.

4）豊田耕一郎ら：腰椎椎間孔外側ヘルニアに対する骨形 成的偏側椎弓切除. 春椎脊髄, $7: 597-601,1994$.

5）吉田宗人：内視鏡視下春椎手術の適応と限界。関節外 科, $25: 1040-1043,2006$.

6) 吉田宗人ら：腰椎椎間板へルニアに対する MED の適 応と臨床成績。臨整外, 40:371-377, 2005. 